\title{
Follow-up management and the management of high versus low risk patients in primary care
}

\author{
Bertine Flokstra \\ From Food Allergy and Anaphylaxis Meeting 2011 \\ Venice, Italy. 17-19 February 2011
}

The main aim of this presentation is to give an overview on the follow-up management of food anaphylactic patients and to address the question of which patients should be prescribed an epinephrine auto-injector (EAI) in primary care. Practical recommendations on these issues will be discussed.

A short introduction will be given on the definition of anaphylaxis and the prevalence and incidence of food anaphylaxis in primary care. Although definitions of anaphylaxis do exist, it is not always easy to identify anaphylaxis because the symptoms may be nonspecific and variable. However, it has been shown that the incidence and prevalence of anaphylaxis has increased in primary care.

Once a patient has experienced an anaphylactic reaction, follow-up management is very important. These patients should be referred to an allergy specialist for further evaluation of the food allergy. Meanwhile, these patients should be prescribed an EAI and receive information on how and when to use it. If the culprit food allergen is know, the patient should receive information about avoidance of this food.

In addition, the primary care physician may see other food allergic patients as well who have not (yet) experienced an anaphylactic reaction. In order to decide which of these food allergic patients should be prescribed an epinephrine auto-injector (EAI), an estimation of the risk for anaphylaxis should be made. By taking into account risk factors for anaphylaxis, patients can be divided into low and high risk patients, which will determine further management strategies.

Published: 12 August 2011

University Medical Center Groningen, Department of General Practice, Groningen, Netherlands

C Biomed Central

( 2011 Flokstra; licensee BioMed Central Ltd. This is an open access article distributed under the terms of the Creative Commons Attribution License (http://creativecommons.org/licenses/by/2.0), which permits unrestricted use, distribution, and reproduction in any medium, provided the original work is properly cited.
doi:10.1186/2045-7022-1-S1-S62

Cite this article as: Flokstra: Follow-up management and the management of high versus low risk patients in primary care. Clinical and Translational Allergy 2011 1(Suppl 1):S62.

Submit your next manuscript to BioMed Central and take full advantage of:

- Convenient online submission

- Thorough peer review

- No space constraints or color figure charges

- Immediate publication on acceptance

- Inclusion in PubMed, CAS, Scopus and Google Scholar

- Research which is freely available for redistribution Submit your manuscript at
www.biomedcentral.com/submit C Biomed Central 